\title{
The effects of hurricanes on birds, with special reference to Caribbean islands
}

\author{
JAMES W. WILEY and JOSEPH M. WUNDERLE, JR.
}

\section{Summary}

Cyclonic storms, variously called typhoons, cyclones, or hurricanes (henceforth, hurricanes), are common in many parts of the world, where their frequent occurrence can have both direct and indirect effects on bird populations. Direct effects of hurricanes include mortality from exposure to hurricane winds, rains, and storm surges, and geographic displacement of individuals by storm winds. Indirect effects become apparent in the storm's aftermath and include loss of food supplies or foraging substrates; loss of nests and nest or roost sites; increased vulnerability to predation; microclimate changes; and increased conflict with humans. The short-term response of bird populations to hurricane damage, before changes in plant succession, includes shifts in diet, foraging sites or habitats, and reproductive changes. Bird populations may show long-term responses to changes in plant succession as second-growth vegetation increases in stormdamaged old-growth forests.

The greatest stress of a hurricane to most upland terrestrial bird populations occurs after its passage rather than during its impact. The most important effect of a hurricane is the destruction of vegetation, which secondarily affects wildlife in the storm's aftermath. The most vulnerable terrestrial wildlife populations have a diet of nectar, fruit, or seeds; nest, roost, or forage on large old trees; require a closed forest canopy; have special microclimate requirements and/or live in a habitat in which vegetation has a slow recovery rate. Small populations with these traits are at greatest risk to hurricane-induced extinction, particularly if they exist in small isolated habitat fragments.

Recovery of avian populations from hurricane effects is partially dependent on the extent and degree of vegetation damage as well as its rate of recovery. Also, the reproductive rate of the remnant local population and recruitment from undisturbed habitat patches influence the rate at which wildlife populations recover from damage.

\section{Introduction}

Environmental catastrophes are of particular interest and concern to conservation biologists because of their potential impact on small populations. These concerns arise, in part, from models of population viability which indicate that catastrophes can cause extinction of small populations (Ewens et al. 1987). Interest is likely to increase given the increasing loss and fragmentation of habitat in much of the world, where more species will exist in small isolated populations, thereby becoming more vulnerable to catastrophic events. Survival of small populations in habitat fragments becomes more precarious if the destructive potential of catastrophes increases, as predicted for cyclonic storms assuming increased global warming (Emanuel 1987). 
Cyclonic storms, variously called typhoons, cyclones, or hurricanes (henceforth hurricanes), are found throughout the world (Nalivkin 1983), with most frequent occurrence in the Caribbean and south-eastern United States; eastern Pacific along the Mexican coast; western Pacific along the north coast of Australia, throughout Indonesia, Malaysia, South-East Asia north to Japan; northern Indian Ocean, along the coast of Bangladesh and India; and western Pacific Ocean including Madagascar and the east coast of Africa. Even in some parts of the north temperate zone, hurricanes can sweep across continents causing extensive destruction, as recorded throughout Europe (Nalivkin 1983).

Although the frequency of hurricane occurrence varies within a region, the re-occurrence rate can be high as illustrated by the return rates of hurricanes in the south-eastern United States and the Caribbean: once every 15 years for Jamaica (Neumann et al. 1990), once every 16 years to coastal South Carolina (Hooper et al. 1990), once every 20 years in south Florida (Lugo et al. 1976), and once every 22 years for Puerto Rico (Weaver 1986). The swath of destruction can also be wide, as substantial damage has been detected 43 to $60 \mathrm{~km}$ from the track of the hurricane eye (Wadsworth and Englerth 1959, Thompson 1983). In some of these regions, hurricanes occur with sufficient frequency and destructive force to be important factors in determining the structure and species composition of biotic communities (e.g. Wadsworth and Englerth 1959, Odum 1970, Crow 1980, Doyle 1981, Weaver 1986). The ecological importance of hurricanes in influencing biotic communities is consistent with the prevailing view that natural systems are largely organized by disturbance (Pickett and White 1985, Denslow 1987).

Given their frequency and potential power, it is not surprising that the effects of hurricanes on human life and property have been well documented (e.g. Anthes 1982, Saffir 1991, Sparks 1991). Descriptions of the effects of hurricanes on wildlife have been widely scattered throughout the literature for some time. Many of the major effects of hurricanes on bird populations were recognized by Clark (1906) and are evident in his vivid description of a storm's impact on bird populations:

On September 11, 1898, St Vincent experienced one of the most destructive hurricanes that has ever occurred in the West Indies. The center of the storm passed directly over the island, and the interior forest as well as the fruit trees on the cultivated areas were almost entirely destroyed. On the next day the island appeared as if it had been swept by fire: there was not a leaf nor any green thing in sight. Everything was brown. The number of birds was very sensibly diminished, those of the "high woods", especially the [St Vincent] parrots [Amazona guildingii], appearing to have suffered the most. Hundreds, if not thousands of birds were killed on the island, and quantities were driven out to sea and lost. Allenia albiventris [Scaly-breasted Thrasher, Margarops fuscus] after the storm became a common resident on Union Island and Carriacou (possibly on some of the other Grenadines also), places where previously it had been unknown. It has since, however, died out at both places. One or two [St Vincent] parrots were picked up dead on the shores of St Lucia. The effects of the storm were not felt all at 
once. For days afterwards parrots and "Ramier" [Scaly-naped Pigeon Columba squamosa] would stray into the smaller towns in so helpless a condition that many fell prey to the negroes. It is possible that starvation was the cause of this, as every green thing had been destroyed, and it was several days before the trees began to put forth buds. When the vegetation did begin to recover from the shock, the whole island, I was told, presented much the appearance of a rugged New England landscape in the spring. A number of the parrots were obtained alive at this time, and some of them are living in captivity yet.

In this passage, Clark describes many of the direct and indirect effects of hurricanes on avian populations, as well as some of the responses of birds to habitat destruction. Direct effects of hurricanes include mortality from exposure to hurricane winds, rains and storm surges, and geographic displacement of individuals by storm winds. In the aftermath, the indirect effects become apparent and include loss of food supplies or foraging substrates; loss of nests and nest- or roost-sites; increased vulnerability to predation; microclimate changes; and increased conflict with humans. The short-term response of bird populations to hurricane damage, before changes in plant succession, includes shifts in diet, foraging sites or habitats, and reproductive responses. Finally, had Clark remained on St Vincent for a longer time period, he would undoubtedly have documented the long-term response of wildlife populations to changes in plant succession as second-growth vegetation increased in the damaged old-growth forests.

Until recently, descriptions of the effects of hurricanes on wildlife have mostly been anecdotal and lacked prior baseline data for quantitative comparison after the storm's impact (e.g. Huntington and Barbour 1936). However, recent hurricanes have swept across regions where investigators have had adequate prehurricane baseline data for comparison with post-hurricane effects (as reviewed in Woodley et al. 1981, Bénito-Espinal and Bénito-Espinal 1991, Finkl and Pilkey 1991 and Walker et al. 1991).

The purpose of our review is to summarize the effects of hurricanes on bird populations, concentrating on the adverse effects on terrestrial species in an effort to identify the characteristics which make a bird population vulnerable to hurricane damage. Many of our examples come from Caribbean islands where we have personally studied the effects of hurricanes on bird populations. These island examples are especially appropriate to continental areas where habitat fragmentation increases the vulnerability of some species to hurricane impacts.

\section{Limitations of hurricane studies}

Care should be taken when evaluating wildlife population changes attributed to hurricanes, even when excellent pre-hurricane baseline censuses are available for comparison. Pre- and post-hurricane census results may not be comparable for a variety of reasons (Jeggo and Taynton 1981). As a result of hurricane damage and lessened food resources, some species may disperse to nontraditional habitats or wander over a greater geographic area. Defoliated habitats may increase the likelihood of detection, whereas extensive treefalls could 
obscure detection of understorey- or ground-dwelling species. Wunderle et al. (1992) compared potential detectability changes associated with a hurricane, based on detectability ratios derived from bird census data. They found that the number of species that were more detectable after the hurricane was not statistically different from the number of species that were less detectable. Even though some species showed statistically significant changes in detectability after the storm, no obvious relationship was found between changes in a species's detectability ratio and changes in its population estimate. They concluded that although statistically significant changes in detectability ratios were found in some species after the storm, it is unlikely that these changes cause a consistent bias in census results.

\section{Direct effects of hurricanes}

\section{Mortality attributed to rain, wind, and flooding}

Hurricane winds, rain, and wave action are commonly assumed to cause bird mortality directly, although this has often been difficult or impossible to document. Indeed birds, with their advantage of flight, may be able to escape the direct ravages of a severe storm by moving out of its path, provided they have some way of sensing the need to do so. The literature on wildlife mortality from hurricanes is sparse and occasionally contradictory (Cely 1991). Accounts of avian mortality are confined primarily to waterbirds rather than landbirds, although the former group's larger size could bias mortality surveys (Wayne in Tomkins 1934, Cely 1991).

Kennedy (1970) reviewed studies relating to the direct effects of rain on birds, noting that the most important consequence is the wetting of plumage and possible death from hypothermia. Chicks probably suffered to a greater extent than adult birds.

Strong winds and rain together can substantially reduce bird populations. Species commonly found in open and exposed sites, such as seabirds, are especially susceptible to severe storms (Threlfall et al. 1974, Cely 1991). High winds alone can cause mortality in birds (Helmuth 1954, Byrd and Tobish 1978, McNicholl and Hogan 1979). Birds may be killed outright by treefalls or flying debris, or they may be thrown against objects, or high winds might blow them far out to sea where they die of exhaustion and drowning (e.g. Clark 1906, Jeggo and Taynton 1981, Pierce 1990). Jones (1987) suggested that cyclones probably killed some Echo Parakeets Psittacula (eques) echo directly by damaging the hollow limbs in which they seek shelter. Deshayes (in Buffon 1779) suggested that the flight of the Smooth-billed Ani Crotophaga ani was weak, so that many were killed during hurricanes. J.W.W. found an adult Red-shouldered Hawk Buteo lineatus that apparently died from head injuries during Hurricane Agnes. It is likely that 200-400 dead Brown Pelicans Pelecanus occidentalis reported by Cely (1991) following Hurricane Hugo (1989) died as a result of the high winds, although it is not explicitly stated. However, Cely (1991) concluded that most South Carolina birds, except roosting pelicans and other waterbirds, moved out of the path of Hurricane Hugo or sought shelter on the ground. During the height of Hurricane Hugo, J.M.W. observed several species of Puerto Rican 
landbird (Zenaida Dove Zenaida aurita, Common Ground-dove Columbina passerina, Black-faced Grassquit Tiaris bicolor, Bananaquit Coereba flaveola) perching or foraging on the ground on the leeward side of buildings and large trees. Similarly, Sutton (1945) noted that many landbirds moved to the ground during a major hurricane in Florida; he reported only one avian fatality.

Although only 10 dead Red-cockaded Woodpeckers Picoides borealis were found after Hurricane Hugo, Hooper et al. (1990) estimated that $63 \%$ of these woodpeckers in the Francis Marion National Forest were killed or missing, based on the mean number of surviving birds per colony (1.5) and mean number of birds per colony prior to Hugo (4.0). Loss of cavity trees undoubtedly contributed to some of this mortality, because woodpeckers forced to roost outside of cavities are more exposed to inclement weather and predators (Engstrom and Evans 1990).

Storm surges or flooding in lowland areas can cause mortality in some populations. "Heavy mortality" of roosting waterbirds was attributed to a $3.9 \mathrm{~m}$ storm surge, rather than to high winds associated with Hurricane Donna in Florida Bay (Robertson and Paulson 1961). Clapper Rail Rallus longirostris populations suffered an estimated $10 \%$ mortality rate $(20,300$ birds, estimated from dead birds at sample sites) across 31,00o ha of New Jersey saltmarsh, after flooding caused by Hurricane Bell (Ferrigno and Widjeskow 1977).

\section{Change in geographic distribution and migratory pattern}

Storms have been cited as responsible for affecting local movements of animals (Darlington 1938). Birds are particularly vulnerable to displacement by high winds (Murphy 1934, Cruickshank 1939, Hill 1945, McClure 1945, Lowery 1946, Pangburn 1948, Peterson 1948, Mayhew 1949). However, Robertson and Kushlan (1974) cautioned that "hurricane transport, particularly of small land birds, seems to have been accepted rather uncritically ... During hurricanes most land birds seek shelter on or near the ground . . . and, despite the enormous energy of hurricanes, the common vision of such birds being swept away by the winds is probably incorrect". Nevertheless, severe storms over the North Atlantic are credited with bringing a spectacular influx of Northern Lapwings Vanellus vanellus from Europe to North America (Bagg 1967) and Dovekie (Little Auk) Alle alle to Cuba (Murphy and Vogt 1933). Seabirds are commonly blown inland, and southern shorebirds are often displaced northward with the northward movement of tropical storms. This frequently occurs on the east coast of North America where southern shorebirds, including terns, skimmers, pelicans and frigatebirds, as well as pelagic species such as shearwaters, petrels, tropicbirds and Sooty Terns Sterna fuscata, have been displaced by storms well to the north of their normal range (Ciferri in Wetmore 1931, Newman and Andrle 1961, Pettingill 1970, Hall 1981, Legrand 1985, DeBenedictis 1986). Although these birds may remain inland for a few days in the aftermath of a storm, many individuals are found dead or emaciated, suggesting that the mortality rate for such storm-driven waifs may be high.

Hurricanes have the potential to disrupt migration, as documented by several observers. For example, displacements of migrant shorebirds to West Indian islands have also been attributed to the effects of hurricanes (Potts 1927, Murphy 
and Vogt 1933). Fisk (1979) attributed the exceptional wave of fall migrants detected at her banding station in south Florida to Hurricane Gerda. Thurber (1980) suggested that Hurricane Fifi (September 1974) was responsible for that fall's unusual bird migration in El Salvador and that such storms affect migration patterns in Middle America. Hurricane Fifi had four major influences on bird migration: the storm caused local concentrations of migrants, deflected individuals from their normal routes, brought about at least temporary extensions of winter ranges, and delayed passage of certain species. In contrast, Fletcher (1989) reported that arrival dates of migrating warblers in parts of Jamaica were not delayed by the passage of Hurricane Gilbert (10 September 1988). Yunick (1977) reported nocturnal migration, exhaustion and death of the normally diurnal Barn Swallow Hirundo rustica in the Caribbean during a hurricane.

Thurber (1980) suggested that the extension of the winter ranges of a few Nearctic species into El Salvador, should these prove permanent, would show that cyclonic storms can have a lasting effect on the distribution of migrants by introducing species into new areas that become suitable for winter habitat. Darlington (1938) believed that hurricanes were an important dispersal agent of fauna in the Greater Antilles. For instance, the Lesser Antillean Bullfinch Loxigilla noctis may have been introduced to the Virgin Islands by Hurricane Donna (Raffaele and Roby 1977). The European Starling Sturnus vulgaris was first sighted at St Ann, Jamaica, just after a hurricane in 1944 (Jeffrey-Smith 1953). The now-common American Kestrel Falco sparverius was first sighted on Mona Island in 1935 (Danforth 1936b) and its arrival may have been associated with a 1930 hurricane which struck Hispaniola, where it is common (Bond 1946). Similarly, the Smooth-billed Ani is believed to have first arrived on Mona following the same hurricane, although it has remained rare (Raffaele 1973).

Conversely, hurricanes may further alter fragments of remaining wintering habitat thereby affecting survival of wintering residents, such as Bachman's Warbler Vermivora bachmani in Cuba (Amadon 1953, Arendt 1992a; but see Hamel 1986).

\section{Indirect effects of hurricanes on birds}

\section{Loss of food supplies}

Defoliation is a conspicuous effect of major storms and, although variable in both degree and extent, it is the commonest type of damage caused by hurricanes (Brokaw and Walker 1991). The high winds which strip leaves from trees also remove flowers, fruits, and seeds, thereby eliminating the food supply for many species. Following a major hurricane on Dominica, Snyder and Snyder (1979) commented on the relative absence of most fruit. Even after more than one year following Hurricane David, production of flowers and fruits was still less than $50 \%$ of pre-hurricane levels on Dominica (Zamore 1981). One month after the passage of Hurricane Hugo, J.M.W. found substantial declines in flowers and fruits (relative to 2.5 years of baseline), including their complete absence at one site, on long-term phenology trails in the Luquillo Mountains of Puerto Rico. Lynch (1991) noted the absence of flowers and fruits in the aftermath of Hurricane Gilbert in the defoliated forests of Yucatán. Swindell (1950) 
described extensive hurricane damage to acorn and other seed crops in Florida, and noted that the larger canopy trees, which are usually superior mast producers, were those most affected by hurricane damage, as also observed by others (Gunter and Eleuterius 1971, Platt et al. 1986, Cely 1991).

In the aftermath of hurricanes, following major loss of flowers, fruits and seeds, observers have found birds concentrated around remnant food sources, including some species that show superior fruit or seed retention. For example, Snyder and Snyder (1979) found that royal palms Roystonea sp. retained their fruits in spite of high winds, and that frugivorous birds of all sorts were concentrated around these food sources on Dominica following a major hurricane. Two weeks after the passage of Hurricane Hugo, J.M.W. observed three species of nectarivores feeding abnormally close to the ground $(<1.0 \mathrm{~m})$ on the flowers of windthrown Inga vera trees in the Luquillo Mountains of Puerto Rico. In the same forest four months after the passage of Hurricane Hugo, fruit-eating birds concentrated in fruit-rich but small $\left(120-150 \mathrm{~m}^{2}\right)$ pre-existing treefall gaps, where mist-net capture rates were exceptionally high relative to those in nearby pre-existing forest understorey, where fruit was absent (Wunderle 1990).

Given that hurricane winds strip flowers, fruits and seeds from plants, it is reasonable to expect that populations of nectarivores, frugivores or seed-eaters are more likely to decline in the aftermath of a hurricane than insectivores or raptors. Indeed, recent hurricane studies of birds have documented this pattern in sites with varying degrees of vegetation damage in a diversity of habitats, including lowland rainforests of Nicaragua (Boucher 1990), subtropical dry forests in Yucatán (Lynch 1991), montane habitats in Jamaica (Wunderle et al. 1992), subtropical wet forest in Puerto Rico (Waide 1991a), subtropical dry forest on Guadeloupe (Bénito-Espinal and Bénito-Espinal 1991), wet montane forest in Dominica (J.W.W., unpubl. data), subtropical dry woodland and subtropical moist forest on both St John (Askins and Ewert 1991) and St Croix (Wauer and Wunderle 1992), and mature evergreen forest in Mauritius (Cheke 1987). These declines in primary consumer populations may, in part, reflect site or habitat shifts (see section below entitled Foraging sites and habitat shifts).

It is not surprising that raptor populations remain unchanged after a major hurricane (e.g. Wauer and Wunderle 1992), given the potential increase in detectability of their prey. For many insectivores, arthropod populations might be initially reduced by hurricanes, but because of their shorter life cycles and rapid reproductive rates, they may recover more quickly than vegetation. In addition, some insect populations (e.g. Coleoptera, Diptera, Lepidoptera) may survive storms as larvae or pupae in protected sites in the soil, in leaf-litter and under bark (Wolcott 1932, B. Freeman verbally). Also, some arthropod populations have shown major outbreaks following hurricanes, possibly as a result of decreased predation and increased food resources (Thompson 1983, Waide 1991b, Torres in press). Thus, many insectivore populations might be buffered from hurricane-induced food shortages by relying on a food source characterized by a high level of diversity, resiliency and turnover.

Population declines of waterbirds related to changed food supplies following hurricanes have been reported. Shepherd et al. (1991) discovered extensive damage to freshwater habitats through saltwater intrusion in South Carolina following Hurricane Hugo's passing. They related the decline $\left(>_{10,000}\right.$ pairs in 
1989 to $o$ in 1990) in the breeding population of White Ibis Eudocimus albus to this disturbance of local freshwater feeding sites and the subsequent reduced availability of freshwater crayfish. Schmitz and Baldassarre (1992) related a sharply elevated feeding rate of Greater Flamingos Phoenicopterus ruber to Hurricane Gilbert, which probably influenced a change in food abundance and availability in their Yucatán study area.

\section{Loss of foraging substrate}

Whereas post-hurricane food loss can explain many population declines, factors such as changes in foliage distribution and vegetation structure can also affect certain species. Loss of high-canopy foraging substrates undoubtedly explains the absence of Black-and-white Warblers Mniotilta varia from montane pine plantations and their decline in lowland coffee plantations on Jamaica following Hurricane Gilbert (Wunderle et al. 1992). The overstorey trees in these habitats suffered substantial loss of branches and twigs, where this wintering Nearctic migrant normally gleans insects. Similarly, the extensive hurricane damage to mimosaceous trees in the overstorey of lowland shade coffee, lowland pasture and ruinate scrub in dry limestone probably contributed to the decline of wintering migrant Prairie Warblers Dendroica discolor, which glean insects from their leaves (Wunderle et al. 1992). Thus, it appears that gleaning insectivores are especially vulnerable to the loss of foraging substrates resulting from hurricane impacts.

Hurricane damage to a Jamaican forest may have contributed to the low return rate in October of banded Black-throated Blue Warblers Dendroica caerulescens to their winter territories (Holmes and Sherry 1992). Although banded Blackthroated Blue Warblers showed a high return rate in October to their winter territories in a hurricane-damaged forest in Puerto Rico, a higher proportion than normal disappeared in the next several months (J.M.W. unpubl. obs.). Perhaps this Nearctic migrant abandoned traditional wintering sites because of loss of foliage from which it normally gleans insects.

Hurricanes are important to mangrove ecosystems as mechanisms for "flushing" accumulated organic materials from estuarine systems. However, estuary substrate changes caused by hurricanes can affect foraging by dependent waders. Schmitz et al. (1990) suggested that estuarine habitat changes caused by Hurricane Gilbert resulted in increased foraging times by a Yucatán population of Greater Flamingos, which had switched to feeding at abnormal substrate depths. Furthermore, they suggested that ingestion of accumulated lead shot deposited at those depths before the hurricane contributed to lead poisoning in the birds.

\section{Loss of nests, nesting sites or roosting sites}

Nests, nesting sites, nesting material and roosting sites can be destroyed by high winds, rainfall or flooding. For example, McNicholl (1979) reported the effects of a wind and rain storm on the breeding marsh birds in Manitoba: $59 \%$ 
(17) of 29 nests under observation did not survive the storm, and survival of eggs or chicks was even lower $-76 \%$ (57/75) succumbed.

Shepherd et al. (1991) reported substantial declines in some species of breeding wading birds (White Ibis, Great Egret Casmerodius albus, Tricoloured Heron Egretta tricolor), whereas other species (Snowy Egret E. thula, Glossy Ibis Plegadis falcinellus) showed less change in breeding populations following the passage of Hurricane Hugo in South Carolina. They suggested the decline in some species was related to habitat changes, whereas other species (Snowy Egret) may have benefited from these changes. Alleng (1990) noted that despite extensive habitat damage caused by Hurricane Gilbert in the mangroves of Jamaica's south coast, a small population of waterbirds continued to use the site for breeding, showed no change in population size, and exhibited only minor behaviour adjustments.

Species requiring large old trees for nesting or roosting are particularly susceptible to hurricane effects. For example, tall trees and trees with larger diameters at breast height were more likely than shorter trees to snap or be uprooted by Hurricane Hugo in Puerto Rico (Walker 1991, You and Petty 1991) and in South Carolina (Gresham et al. 1991, Putz and Sharitz 1991). Similarly, tall trees were especially prone to direct wind damage on St John, Virgin Islands (Reilly 1991). Trees which had sustained previous mechanical damage were more damaged during Hurricane Hugo than trees with no previous damage in the Congaree Swamp, South Carolina (Putz and Sharitz 1991). This suggests that wildlife using storm-damaged old trees for nests or roost-sites runs the risk of losing these sites in future storms.

Bald Eagles Haliaeetus leucocephalus in the south-eastern United States typically nest in large exposed pines which are susceptible to hurricane wind damage (Broley 1951, 1957). This was evident following Hurricane Hugo in South Carolina where $44 \%(24 / 54)$ of the state's Bald Eagle nests were destroyed (Cely 1991). Although no eagles were reported dead, 18 nest-trees were blown down. Many of the eagle territories had few suitable large pines remaining which might serve as alternative nest-sites. Yet despite major habitat changes, including disturbance from timber salvage operations, eagles showed a high degree of site fidelity and rebuilt nests in 21 of the 24 damaged territories. In the breeding season following the hurricane, nest-building got under way too late in the season to produce young on some territories. Nonetheless, hurricane destruction of eagle nests caused only a temporary set-back to the Bald Eagle recovery in South Carolina (Cely 1991).

Temple (1978) reported that the majority of known nest-trees of the cavitynesting Mauritius Parakeet were toppled by Cyclone Gervaise (1975). Although nest-sites were not considered to be limiting to the population, the loss of sites through storm damage may have increased the importance of nest-site competition with other species (Jones 1980).

Jeggo and Taynton (1981) believed that the effect Hurricane Allen had on the availability of St Lucia Parrot Amazona versicolor nest-sites was of greater significance to the population than temporary depression of food supplies. Of the four known nest-sites, three were still standing after the storm, although other large trees around them had been blown down. The fourth tree was 
completely destroyed. Nichols (1981) reported that two known nest cavities used by parrots on Dominica before Hurricane David were destroyed by the storm. All three remaining known sites had been changed and only two were reused.

Snyder (1977), Wiley (1980, 1985a), and Snyder et al. (1987) discussed the probable role of hurricanes in reducing availability of nesting cavities suitable for the Puerto Rican Parrot Amazona vittata in certain parts of the Luquillo Forest. The rarity of cavities in the western forest relative to other parts of the Luquillo Mountains and the presence of many dead trees on that side of the forest may be the result of the two hurricanes that hit that forest in 1928 and 1932. Conversely, trees that suffer limb breakage, but remain standing, might be susceptible to cavity formation and, therefore, provide future nest-sites for hole-nesting species (Snyder et al. 1987). Fungal outbreaks and insect attacks may increase following hurricanes (Bates 1930), and hurricane damage may provide the initial foothold needed to infest trees. Nevertheless, in the short term, the loss of trees throughout the forest undoubtedly decreases the incidence of cavity trees.

A hurricane that savaged Little Cayman in 1932 has apparently had longlasting effects on the population of the Cayman Brac Parrot Amazona leucocephala hesterna, which formerly occurred there (Bradley 1986). A viable population has not returned to the island since the hurricane, which severely damaged most of the island's trees. Vegetation surveys conducted in 1992 revealed that nesting cavities were rare compared with Cayman Brac habitat (F. Burton and J.W.W. unpubl. data).

A species found to be highly vulnerable to hurricane destruction of nest/roost-sites is the small, colonial Red-cockaded Woodpecker, which is endemic to old-growth pine-forests in the south-eastern United States and which constructs its nest and roost-cavity in living, older pines (60-90 years old), often infected with redheart, a fungal disease (Baker 1971, Jackson et al. 1979, Lennartz et al. 1983). Excavation of a cavity typically requires several years, and once completed the cavity may be used for as many as 20 years. Cavity trees are a critical resource for the woodpecker, and the lack of potential trees for cavity excavation is a primary reason for its endangered status (U.S. Fish and Wildlife Service 1985).

The vulnerability of Red-cockaded Woodpecker nest/roost-cavity trees to hurricane destruction has been well documented. Of 33 Red-cockaded Woodpecker cavity trees inspected by Engstrom and Evans (1990) during autumn 1985, four were killed during Hurricane Kate (1985). Woodpecker cavities appeared to contribute to the likelihood of wind-induced mortality, as evidenced by the finding that six of the eight cavity trees killed in the autumn of 1985 were snapped off at the site of the woodpecker cavity; trunks of the remaining two trees broke below the cavity. However, the effect of the woodpecker cavities may have been compounded by redheart, as five of the eight woodpecker cavity trees that snapped off had rotten heartwood. Redheart was not apparent at the site where the trunk snapped in the remaining three trees. Four other cavity trees suffered a loss of large limbs or a gash in the trunk, which increases the likelihood of future mortality.

Hurricane Hugo, which swept through Francis Marion National Forest, South Carolina, containing one of the largest populations (approximately 500 breeding 
units) of Red-cockaded Woodpeckers, resulted in catastrophic loss of cavity trees and woodpeckers (Hooper et al. 1990). Hugo knocked down approximately $70 \%$ of the sawtimber $(>3.6 \mathrm{~cm}$ diameter breast height) on the national forest, thereby destroying $87 \%$ of the 1,765 active cavities used by the woodpecker before Hugo. In the active colony sites (with a minimum of one active cavity), an average of 1.9 cavities were active in a post-hurricane sample of 205 colony sites, compared with an average of 3.7 active cavities in 100 randomly selected active colony sites in 1988, before Hugo. Thus, the availability of cavities per active colony of woodpeckers decreased substantially after Hugo.

Whereas the storm contributed to substantial Red-cockaded Woodpecker mortality, the issue of greatest concern is the long-term impact on the forest and the future availability of potential cavity trees (Hooper et al. 1990). As a result of the hurricane, potential cavity trees will continue to show high mortality rates as a result of the increased likelihood of disease, insect outbreaks, and catastrophic wildfires. In the absence of management intervention, this population of Red-cockaded Woodpeckers could remain depressed for a long time, given the loss of potential cavity trees and the time required for cavity excavation.

Hurricane-related destruction of large trees could also destroy roosting sites. For example, Cattle Egrets Bubulcus ibis abandoned a traditional roost-site on St Croix after Hurricane Hugo toppled the large trees in which they previously roosted (Wauer and Wunderle 1992).

Materials required for nest construction may also be lost during hurricanes. The American Swallow-tailed Kite Elanoides forficatus abandoned nest-sites in parts of southern Florida after hurricanes destroyed the Spanish moss Tillandsia usneoides, a material commonly used in kite nests (Bent 1937).

Flooding of nests or nest-sites, as a result of storm surges, can affect some populations in low-lying areas. For example, Ring-necked Pheasant Phasianus colchicus populations experienced minor losses from flooding caused by Hurricane Agnes in Pennsylvania (Hartman and Wunz 1974). Beach erosion can eliminate shorebird nesting sites, or at least make the remaining sites more vulnerable to high tides. Holliman (1981) reported that alteration of sand and Spartina distribution caused by Hurricane Frederic (1979) in Alabama marshes subsequently affected Clapper Rail distribution. Although pre-storm population levels of rails persisted in areas where Spartina marshes were not substantially altered, rail populations declined considerably in marshes reduced in size by sand deposits or debris.

In the Virgin Islands, habitat changes resulting from Hurricane Hugo apparently caused more than 300 Red-footed Boobies Sula sula to forego nesting on the affected cays, whereas breeding habitat for Sooty Terns Sterna fuscata was increased (Pierce 1990, 1991). Saliva (1989) reported different responses to nesting habitat changes among several seabirds nesting in the Culebra Archipelago. Species whose nesting habits depend on vegetative cover (Sooty Tern, Brown Noddy Anous stolidus, Audubon's Shearwater Puffinus lherminieri, Red-footed Booby) or cavities formed by rocks (White-tailed Tropicbird Phaethon lepturus, Red-billed Tropicbird $P$. aethereus, Bridled Tern Sternus anaetheus) were negatively affected (Saliva 1989, Pierce 1991): the strong winds and salt spray defoliated and killed the vegetation, and trees were snapped or uprooted, thereby 
creating gaps in the vegetative cover, while heavy wave action shifted or removed rocks that formed nesting cavities. In contrast, some species (Sandwich Tern Sterna sandvicensis, Royal Tern S. maxima) breeding in the archipelago may have been positively affected by Hurricane Hugo through the creation of more favourable open areas, while three nesting species (Brown Booby, Masked Booby Sula dactylatra, Roseate Tern Sterna dougallii) were apparently unaffected by storm-caused habitat changes (Saliva 1989). Certain species are able to adapt to some habitat changes wrought by hurricanes. Following Hurricane Hugo, Brown Pelican populations in the Virgin Islands fledged above-average numbers of chicks after pairs adapted to habitat destruction by nesting on downed vegetation (Pierce 1990).

\section{Increased exposure to predation}

Birds are likely to be more exposed to predators in defoliated habitats in the aftermath of hurricanes. Unfortunately, we are unaware of any published accounts supporting this idea, probably because of the difficulty of observing predation and assessing its impact on prey populations. Raptors are certainly present and often quite visible after hurricanes. American Kestrel and Red-tailed Hawk Buteo jamaicensis populations on St Croix were unaffected by a hurricane (Wauer and Wunderle 1992), whereas after a hurricane in Yucatán one raptor species (Ferruginous Pygmy-Owl Glaucidium brasilianum) declined and another (Roadside Hawk Buteo magnirostris) was unaffected (Lynch 1991). In the two months after the passage of Hurricane Hugo through the Luquillo Forest, Pearly-eyed Thrasher Margarops fuscatus depredations of Anolis lizards and birds entangled in mist-nets were unusually frequent (J.M.W. unpubl. data).

\section{Forest canopy loss}

Many forest-floor or understorey species are accustomed to foraging in dark lower forest strata and are likely to leave areas with reduced canopy cover. Whether these animals are responding directly to the absence of a canopy or to one of the secondary effects resulting from canopy loss (e.g. change in light level, microclimate, food supply, predator exposure, vegetation structure) is unknown.

Canopy loss may have contributed to post-hurricane declines in Ovenbird Seiurus aurocapillus populations in wet limestone forest and lowland shade coffee on Jamaica (Wunderle et al. 1992). Ovenbirds are insectivorous Nearctic migrants that normally feed on the forest floor where a canopy is found on their wintering grounds (Lack and Lack 1972). Similarly, the ground-foraging Ruddy Quail-dove Geotrygon montana is commonest under a closed canopy (Wunderle et al. 1987). In the aftermath of Hurricane Hugo, quail-doves disappeared from forest sites with canopy loss, but remained in nearby forest patches with intact canopy (Wunderle 1990, Waide 1991a). A similar species, the Bridled Quail-dove G. mystacea, also declined in sites with canopy damage on St John and St Croix (Askins and Ewert 1991, Wauer and Wunderle 1992).

Canopy loss may have contributed to the decline or complete disappearance of the typical lowland forest understorey species in Nicaragua in the aftermath 
of Hurricane Joan. Most forest understorey species in the families Dendrocolaptidae (woodcreepers), Formicariidae (Antbirds) and Furnariidae (ovenbirds) were rare or absent after the hurricane (Will 1991). This response is not surprising given that many forest understorey species in lowland Neotropical forests on the continent are notoriously sensitive to light gaps (e.g. Willis 1974).

\section{Microclimate changes}

Loss of the forest canopy can have profound effects on the microclimate of the forest understorey (Waide 1991b). Higher temperatures and desiccation may stress organisms adapted to life in the shaded understorey of a closed-canopy forest. Whereas microclimatic changes following a hurricane may affect some higher vertebrates, the effect is likely to be greatest upon ectotherms with limited dispersal abilities, such as some of the lower vertebrates and invertebrates (Reagan 1991, Willig and Camilo 1991, Woolbright 1991). Population changes in these organisms will have concomitant effects on the birds that prey on them.

\section{Effects of man's activities on wildlife after hurricanes}

The negative effects of human activities on wildlife may increase in the aftermath of a major storm. Storm-weakened wildlife often provide a readily available and vulnerable source of protein for people who may be in need of food themselves (e.g. Labat 1742, Clark 1906). This may have occurred on Dominica, where populations of the Imperial Parrot Amazona imperialis probably suffered mortality from hunting pressure by men seeking food in the parts of the island heavily damaged by hurricanes in 1979 (Snyder and Snyder 1979, J.W.W. pers. obs.). The tendency for wildlife to wander widely in search of food and cover in the aftermath of storms makes them even more vulnerable, particularly when they move into agricultural or residential areas. The appearance of parrots in agricultural regions in the aftermath of hurricanes has been widely reported (Thompson 1900, Clark 1906, Porter 1929, Varty 1991), and may bring them in to direct conflict with man, further contributing to their mortality.

Hurricanes may open primeval forests to human exploitation or increase the likelihood of human-caused fire damage. Logging (along with hunting and chick harvesting) in the Rio Abajo Forest after the 1899 hurricane exerted heavy pressure on the remnant Puerto Rican Parrot flocks, which disappeared within 30 years (Snyder et al. 1987). Opportunistic logging of Dominican forests damaged by hurricanes in 1979 resulted in new intrusion routes and further fragmentation of Imperial and Red-necked Parrot habitat (Evans 1991). Opportunistic land settlement by subsistence farmers may encroach on woodlands, where forests have been blown down by hurricanes (e.g. Varty 1991, J.W.W. pers. obs.). Local and international governments sometimes make subsidies available for timber removal and development of the land. This relief has included the provision of chainsaws and even heavy equipment to help hurricane victims clear away debris and dead trees. Many times such equipment is not recalled following the clean-up of the storm, and is put to use in clearing healthy forests (Varty 1991). Furthermore, local government and international programmes for economic 
"recovery" following hurricanes may further contribute to forest and habitat loss.

\section{Responses of bird populations to hurricane effects}

\section{Diet shifts}

One option for some species which have lost their main food source in the aftermath of a hurricane is to shift to another food source. For example, parrots fed on fallen bananas outside their normal range after hurricanes passed over St Lucia (Snyder and Snyder 1979, Jeggo and Taynton 1981, J.W.W. pers. obs.). The Antillean Euphonia Euphonia musica, considered to be a diet specialist on the fruit of mistletoe Phoradendron spp., was observed feeding on the fruits of eight additional species of plant and on arthropods after Hurricane Hugo damaged the forest canopy to which the mistletoe was confined (Pérez-Rivera 1991).

Diet shifts were evident in the stomach contents obtained from several bird species before and after the passage of Hurricane Hugo through the Luquillo Forest on Puerto Rico (Waide 1991a). A diet shift occurred in the proportions of various arthropod taxa; Coleoptera were less frequently found in stomachs before the hurricane than after $(20 \%$ vs. $68 \%$ of the stomachs examined). In contrast, Hymenoptera (37\% vs. 10\%) and Araneida (29\% vs. $12 \%$ ) were both commoner before the storm. Although a larger proportion of birds had consumed fruit after the hurricane ( $34 \%$ vs. 59\%), this may have occurred because birds moved into pre-existing gaps where fruit was abundant (Wunderle 1990).

\section{Foraging sites and habitat shifts}

Hurricanes can disrupt the normal vertical stratification of foraging sites within forests, thereby constraining inhabitants to forage at one level, and possibly increasing the likelihood for competition or risk of predation. If a bird's normal food supply or foraging site has been damaged or destroyed, it might be expected to shift its foraging location shortly after the storm's passage and well before plant succession occurs. For some species this might involve a shift in foraging site within the same habitat, such as forest canopy-dwelling species foraging near the ground following canopy loss in the wake of a major storm. For instance, after Hurricane Hugo severely damaged the canopy of the Luquillo Forest in Puerto Rico, initial mist-net capture rates of canopy-dwelling birds at ground-level were approximately four times greater than pre-hurricane rates, whereas capture rates of forest understorey species were unchanged (Wunderle 1990). This increase in canopy-dwellers at ground-level also contributed to the initially high counts of birds observed in censuses there (Waide 1991a).

Some species may respond to hurricane-damaged habitats by foraging more within the original home range or by expanding their home range size to forage over a greater area. Thus, foraging site shifts might involve limiting activities to less damaged areas of the same habitat or expansion of activities into other nearby habitats, thereby accounting for the post-hurricane appearance of some 
species in atypical habitats. For example, G. Charles (in Jeggo and Taynton 1981) reported that large flocks of St Lucia Parrots were seen wandering in unusual localities in search of food after Hurricane Allen destroyed most of their food sources. Similarly, after Hurricane Hugo Puerto Rican Parrots were observed outside the traditional foraging range (M. Wilson verbally, J.W.W. and J.M.W. pers. obs.). After Cyclone Claudette (1979) hit Mauritius Island, Echo Parakeets wandered over greater areas than observed before the storm (Jones 1980, 1987).

Some forest edge/shrub species, such as White-bellied Wren Uropsila leucogastra and Spot-breasted Wren Thryothorus maculipectus, became commoner in the forest interior in the Yucatán 5-6 months after Hurricane Gilbert, but were rare or absent after 17 months (Lynch 1991). Similarly, two months after Hurricane Hugo, the Indigo Bunting Passerina cyanea, an edge and second-growth species, appeared briefly in the interior of the Luquillo Forest for the first time (Wunderle 1990). Following extensive damage by Hurricane Hugo to mature pine-forests in the Francis Marion National Forest, South Carolina, Bachman's Sparrow Aimophila aestivalis became more abundant in clear-cut habitats, where it had previously been rare (Dunning and Watts 1991). The Prairie Warbler, an overwintering Nearctic migrant on Jamaica, decreased from baseline levels in three lowland habitats and increased markedly in nearby mangroves; in addition, they appeared after the hurricane in the middle of defoliated montane cloudforest, a habitat in which they had not been encountered previously (Wunderle et al. 1992). Hooded Warblers Wilsonia citrina, which segregate by sex into preferential habitats (Morton 1990), showed shifts in habitat use in the Yucatán Peninsula following the passage of Hurricane Gilbert: after the storm, females appeared in forests previously occupied only by males, which Morton et al. (1993) attributed to hurricane-caused changes in habitat structure.

Altitudinal movements or population shifts are likely in mountainous regions if high-altitude sites are more severely damaged than lowland sites (e.g. for ridge vs. valleys, see Brokaw and Grear 1991, Frangi and Lugo 1991) and because recovery rates of high-altitude vegetation lag behind those of the lowlands (Bates 1930, Lugo et al. 1983, Varty 1991, Wunderle et al. 1992). This may have been the case in Jamaica, where declines of avian populations were most severe and long-lasting in montane habitats (where trees were still defoliated), whereas population increases were detected in some lowland habitats (where new foliage was present) six months after Hurricane Gilbert (Wunderle et al. 1992). For example, nectarivorous Bananaquits probably emigrated from montane habitats (significant declines in montane pine plantations, montane coffee plantations) and into lowland habitats (significant increases in wet limestone forest, lowland coffee, dry limestone forest). The White-chinned Thrush Turdus aurantius, a widespread Jamaican frugivore, also fits a pattern consistent with inter-habitat or altitudinal migration by disappearing from montane coffee and lowland secondary forest, and increasing in lowland coffee plantations (Wunderle et al. 1992). Similarly, six months after the passage of Hurricane Hugo across the small island of Montserrat, Arendt (1990) found that the endemic Montserrat Oriole Icterus oberi had moved from its traditional dwarfforest habitat on mountain ridges down to regenerated forests between 400 and $700 \mathrm{~m}$ elevation and into steep-sided arroyos in the foothills. Thus, all known 
cases of altitudinal population movements in the aftermath of hurricanes have been from montane to lowland, supporting the notion that high-altitude habitats might be more severely damaged and recover more slowly than lowland habitats.

As foragers on patchily distributed and temporarily available food resources, many tropical nectarivores, frugivores, and seed-eaters range widely and often migrate seasonally and altitudinally in the tropics (e.g. Stiles 1983). Tropical insectivores, which feed on more predictable resources, tend to wander less than nectarivores, frugivores, and seed-eaters. Thus, the reliance on widely distributed and temporary food resources could pre-adapt nectarivores and fruit/seed-eaters to respond to localized hurricane-induced food shortages through emigration.

Post-hurricane wandering may include the movement across open ocean as birds fly between nearby islands after a storm has destroyed familiar foraging sites. Labat (1742) vividly described the effects on birds of a devastating hurricane that hit Dominica and Martinique in 1695:

We noted that day that many birds passed such as parrots, grives [thrushes and/or thrashers], ramiers [Scaly-naped Pigeons], and others taking a route to Dominica only seven leagues from Macouba [northern Martinique]. Perdix [Ruddy and/or Bridled Quail-doves], tourterelles [Zenaida Doves], and ortolans [Common Ground-doves] took the same route, but when they had flown a little way out to sea they headed back to land, so tired and weary they fell without strength to get up, so one could take them by hand. I took a number of them myself. It would have been a waste of powder to shoot them at that time.

The reason these birds were obliged to change their residence is that they could not find any more seeds in the woods to eat. Those of our area apparently thought they could find [food] in Dominica, the nearest land, and those in Dominica thought they could find it here, so that the next day we saw clouds of ramiers, parrots, and grives coming from Dominica, so beaten by hunger and fatigue that some fell in the sea, others on the sand, others in our fields, and others did not have the strength to stay on the branches where they perched upon arrival.

Snyder and Snyder (1979) reported that the formerly common Scaly-naped Pigeons were difficult to find on Dominica after Hurricane David, possibly as a result of food shortages. The Snyders received reports of large influxes of this highly mobile species on the neighbouring islands of Guadeloupe and Marie Galante (Snyder et al. 1987). Similarly, large numbers of doves and pigeons were reported moving to Guadeloupe after hurricanes Frederic and Allen passed over Dominica (J.W.W. unpubl. data). It is conceivable that these extensive movements resulting from hurricane destruction of food supplies might cause an expansion of geographic range.

After Hurricane Hugo, Puerto Rican Parrots expanded their breeding range into a lower transition forest, a zone the population had not used for nesting for at least two decades (Snyder et al. 1987, Meyers et al. 1993). Meyers et al. (1993) suggested parrots may have discovered the new nesting sites while searching lowlands for available foods following the storm. 
Abnormal flocking associations have been noted for some species following storms. Although flocking is normally rare in the Pink Pigeon Nesoenas mayeri of Mauritius, following Cyclone Carol (1960) most, if not all, of the surviving pigeons were apparently foraging in one large group (Jones 1987).

\section{Reproductive response following hurricanes}

Some birds breed normally in the aftermath of a hurricane in spite of substantial habitat damage, although the observed reproductive response can be variable. Despite extensive damage to Jamaica's forests (Bellingham 1991, et al. 1992, Varty 1991, Wunderle et al. 1992), evidence of successful breeding in the following breeding season was observed by Varty (1991) in the Crested Quail-dove Geotrygon versicolor, Blue Mountain Vireo Vireo osburni, Jamaican Blackbird Nesopsar nigerrimus, Yellow-billed Parrot Amazona collaria, but not the Blackbilled Parrot $A$. agilis or Ring-tailed Pigeon Columba caribaea. Puerto Rican Parrots bred in the 1990 breeding period after the passage of Hurricane Hugo, although breeding was delayed by three months (M. Wilson pers. comm.). Although reproductive activity and procuctivity was low in 1990, in 1991 and 1992 reproductive effort and productivity exceeded those for several years before the hurricane. Meyers et al. (1993) suggested these positive changes may be related to the higher nutritive content in the flush of new growth stimulated by the storm's disturbance. In the same forest, Arendt (1992b) found that breeding by Pearlyeyed Thrashers was delayed four months from normal and compressed into a three-month period (in 1990) rather than the normal five months. However, after a hiatus of one month, thrashers bred for almost 12 consecutive months (1991). The number of nesting females per season was significantly lower in the first post-hurricane nesting season, but significantly higher in the second post-hurricane season than during the 10-year pre-disturbance period. Clutchsize in the first post-hurricane breeding season did not differ from 10 years of baseline, but second post-hurricane season clutch-sizes were significantly smaller than in the pre-hurricane period. Hatching and fledging success were similar among pre- and post-hurricane seasons. Arendt noted that the reproductive cycles of other forest birds followed the same pattern exhibited by the thrasher following Hugo. Jones (1987) reported rapid recovery of Pink Pigeon populations after cyclones substantially reduced numbers and suggested that the pigeon's ability to lay multiple clutches is probably an adaptive strategy which helps offset losses caused by severe storms.

\section{Responses to increased second-growth vegetation}

Our discussion so far has focused on the relatively short-term effects of hurricanes and has ignored the long-term successional changes associated with recovery. A major effect of hurricanes is the creation of early successional habitats, by increasing the number and size of forest openings (see reviews in Brokaw and Walker 1991, Tanner et al. 1991). In pre-settlement times, hurricanes were undoubtedly beneficial to wildlife diversity by creating such early successional habitats in landscapes dominated by extensive forests. These storms create a patchwork or mosaic of communities which influences the abundance 
of particular species (Levin and Paine 1974, Whitmore 1974, Paine 1979) and community diversity (Loucks 1970, Connell 1978, Huston 1979). These disturbances provided habitat for edge and second-growth species, which otherwise would have been uncommon or rare in those times. However, today most edge or second-growth species have an adequate amount of habitat in contrast to species requiring mature forest or forest interior, which face the greatest risk of temporary habitat loss from hurricanes.

Certain bird species respond positively to gale-damaged or tornado-damaged forests in north temperate areas (e.g. Woods 1940, Eynon 1951, 1954, Webster 1963, 1964). Northern Bobwhite Colinus virginianus habitat improved after Hurricane Celia passed over the altered mesquite Prosopis glandulosa cover-type in coastal Texas in 1970 (Bell and Klebenow 1973).

In tropical regions, avian species preferring second-growth and edge have responded to successional changes in the aftermath of hurricanes by moving into damaged forests where they had previously been rare or absent (see siteshift discussion). Grey Kingbirds Tyrannus dominicensis and Scaly-breasted Thrashers, which are not normally found in mature forests, became common in hurricane-created gaps in the rainforest on Dominica (J.W.W. unpubl. data). An influx of field- and shrub-associated bird species occurred 5-6 months after the passage of Hurricane Hugo over a dry tropical forest in the Yucatán Peninsula (Lynch 1991). The granivorous Black-faced Grassquit became more abundant in the aftermath of Hurricane Hugo in the Luquillo Forest where it previously had been rare and associated with roadsides and nearby gaps (Wunderle 1990, Waide 1991a). The grassquit appeared in the hurricane-damaged forest at 160 days after the storm, just as annual herbs and grasses set seed in forest openings. However, as the forest floor became shaded by regenerating trees, tree sprouts and saplings, the small seed-bearing plants declined and the grassquits disappeared.

The most dramatic response to forest loss and vegetation re-growth in the aftermath of a hurricane occurred in Atlantic coast rainforest of Nicaragua (Will 1991). Here, in the aftermath of Hurricane Joan, Will compared bird populations, at three months after the storm with intact forest in nearby Costa Rica. His mist-net studies demonstrated that hurricane-damaged forests had proportionately more species typical of forest edge, forest canopy, and second-growth habitats, whereas forest interior species were poorly represented.

Increased forest openings may enable avian brood-parasites and some predators to invade extensive forest tracts which they would otherwise avoid. This could be particularly detrimental to the populations of some forest interior birds, which have been shown to be highly sensitive to edge-dwelling brood-parasites and predators (reviewed in Askins et al. 1990). Avian brood-parasites, such as Brown-headed Molothrus ater and Shiny M. bonariensis Cowbirds, favour fields, openings, and forest edges where they parasitize the nests of a variety of passerine species, and have been implicated in the decline of several (Gates and Gysel 1978, Brittingham and Temple 1983, Terborgh 1990). Predators such as crows, jays, raccoons and blackbirds are mostly confined to forest edge and rarely enter dense intact forest. However, loss of canopy cover could make extensive forest areas more attractive to these edge species, resulting in decreased nesting productivity for sensitive forest-interior species (Brittingham and Temple 1983). 


\section{Discussion}

Most recent studies indicate that relatively little mortality of terrestrial wildlife is attributable to the direct effects of hurricane winds and rain, at least for populations living above flood-prone areas. As Cely (1991) notes, in the wake of Hurricane Hugo in South Carolina mortality of small species could have been overlooked, but the loss of larger species such as deer and turkey undoubtedly would have been noticed by the many fieldworkers. Similarly, in the aftermath of Hugo in the Luquillo Forest, the many fieldworkers would have reported wildlife mortality had it been evident. In addition, the consistent post-hurricane pattern in which terrestrial avian population declines were related to diet indicates that the greatest impact of hurricanes occurs after its passage, rather than during its impact. It seems unlikely that avian insectivores would somehow be less vulnerable to hurricane winds and rains than most avian fruit-, seed- and nectar-feeders residing in the same place. As noted by Wunderle et al. (1992), body size differences (as an indication of vulnerability to wind and rain exposure) are unlikely to explain the diet-related pattern of population change. Moreover, most overwintering Nearctic migrants were absent when Hurricane Gilbert passed over Jamaica, yet the population trends of resident insectivores (which weathered the storm) did not differ from those of the migrants that were absent (Wunderle et al. 1992). These observations, in addition to those of Cely (1991), indicate that most upland terrestrial wildlife populations can survive the direct effects of hurricane winds and rains.

The most important direct effect of a hurricane is the destruction of vegetation, which secondarily affects bird populations in the storm's aftermath. The effects of a hurricane on vegetation depend on its intensity, the width of its path, its velocity of forward movement, the susceptibility of the plants to damage, and the degree of protection afforded by topographic features (Ackerman et al. 1991, Tanner et al. 1991). The avian species most vulnerable to these effects are characterized by having a diet of nectar, fruit or seeds; they nest, roost, or forage on large old trees; and have special microclimate requirements, or live in a habitat in which the vegetation has a low recovery rate. The time period for habitat recovery in the aftermath of a storm varies with the extent and degree of damage to vegetation as well as its inherent ability for recovery. At the extreme are bird species requiring old-growth trees for nesting or roosting, such as Red-cockaded Woodpeckers, which require a tree at least 60 years old and then several years to excavate the cavity (Jackson et al. 1979).

For many large, widespread wildlife populations, recovery from hurricane effects can occur rapidly. For example, declines in avian abundance were detected within six months of hurricanes in Puerto Rico (Waide 1991a), Mexico (Lynch 1991) and Nicaragua (Will 1991). However, both species richness and bird abundance returned to pre-hurricane levels within 9,17 , and 17 months after their respective hurricanes. The two continental sites showed considerable turnover in species immediately after the hurricanes, but after 17 months a return towards the pre-hurricane community was evident. In Nicaragua, species typical of edge and second-growth predominated, whereas forest interior species were still mostly absent at 17 months. In Mexico, most of the edge/second-growth "invaders" had disappeared by 17 months after the hurri- 
cane, and forest interior species predominated, although populations of some forest species still had not recovered. Perhaps recovery of some populations of forest interior species requires closure of the canopy, which could take many years on heavily damaged sites.

Although local extinctions may temporarily occur in hurricane-devastated areas (because of mortality or dispersal into nearby less damaged patches), permanent local extinction can be avoided by recruitment from surrounding areas. This recruitment is known as the rescue effect (Brown and Kodric-Brown 1977) or mass effect (Schmida and Wilson 1985), but is ineffective if the extent of storm damage is great relative to an organism's dispersal abilities. Recruitment rates can further be reduced if the availability of undisturbed habitat patches, which serve as sources for recruitment, becomes limited. Therefore, local extinctions in hurricane-damaged areas become more likely as humans fragment and destroy habitats and thus eliminate potential sources for posthurricane recruitment.

In addition to limiting the availability of source populations for post-hurricane recruitment, habitat fragmentation also increases the number of small habitat patches. Populations inhabiting small patches have an increased likelihood of extinction because of area-independent factors, such as storms (MacArthur and Wilson 1967). Such extinction has been reported for islands (Diamond 1972, Heatwole and Levins 1973) and mainland isolates (Moore and Hooper 1975, Galli et al. 1976, Whitcomb et al. 1981). These extinctions, if local, are not likely to jeopardize the survival of a widespread species. This was undoubtedly the situation 200 years ago when hurricanes destroyed prime forest habitat for the Red-cockaded Woodpecker, which then was widely scattered throughout the south-eastern United States. However, the risks of extinction are greater now that the species occurs in small, fragmented groups, of which only three populations are large enough $(>500)$ to be considered capable of long-term viability (U.S. Forest Service 1985). Hurricane Hugo recently passed through one of the three viable populations, thereby reducing the number of viable populations by one-third (Hooper et al. 1990, Cely 1991). Thus, in this instance, habitat fragmentation has increased the likelihood of extinction, mediated by a hurricane.

Hurricanes have been implicated in the decline of Kirtland's Warbler Dendroica kirtlandii, which winters in many of the Bahama Islands (Trautman 1979). However, the potential for mass destruction of wintering populations is small because the birds are dispersed through the widely separated islands. Nevertheless, warbler population declines have coincided with hurricanes that swept across the northern Bahama Islands in 1964 and 1965 (Ryel 1981).

The Yellow-shouldered Blackbird Agelaius xanthomus was formerly widespread through lowland Puerto Rico, but by the 1970s habitat fragmentation and other environmental problems had reduced the blackbird's range to two disjunct localities on the island (Post and Wiley 1976). The remnant population of blackbirds in eastern Puerto Rico had been in steep decline during the 1970s and 1980s, primarily because of brood-parasitism by the Shiny Cowbird (Post and Wiley 1977, Wiley 1985b). By 1986, approximately 5-8 pairs survived. Following the passing of Hurricane Hugo (1989), no Yellow-shouldered Blackbirds could be found on former study areas (J.W.W. unpubl. data). Whether birds in 
the remnant population were killed outright by the storm or simply dispersed from the site is unknown. Just after the storm, J.W.W. observed Yellowshouldered Blackbirds in other distant, lowland sites where they had not been of regular occurrence in previous years.

Although avian extinctions attributed to hurricanes are rare (0.4\% of 268 bird extinctions: King 1978), the most arguable case is consistent with the risk factors identified in this review. The loss occurred on the West Indian island of St Kitts, where Raffaele (1977) suggested that the extinction of the Puerto Rican Bullfinch Loxigilla portoricensis grandis may have resulted from two hurricanes in 1899 which reduced the population to a level from which it could not recover. At the time of the storms, all but the mountain summit was planted in sugar-cane (Beard 1949); afterwards, the montane fruit and seed supplies were probably destroyed, rendering the fruit- and seed-eating bullfinches unable to find food in the sugar-cane dominated lowlands. Although the population persisted until at least 1929 (Olson 1984), it is likely that it was no longer viable. Thus, in this instance, a combination of hurricane destruction of a food resource in a habitat with slow recovery and the absence of alternative habitats or food sources may have contributed to extinction.

Similarly, direct and indirect effects of hurricanes have been suggested as an important factor in the decline and possible extinction of the Greater Bird-ofParadise Paradisaea apoda on Little Tobago, where it was introduced in 1909 (Dinsmore 1970). By the time Hurricane Agnes (1963) hit the island, the population had dwindled from the 47 or 48 released birds to $15-35$ birds (Gilliard in Dinsmore 1970). After the storm, Dinsmore was able to account for only seven birds.

Interestingly, the historical accounts of population declines attributed to hurricanes contain examples of species having at least one of the risk factors known to contribute to hurricane vulnerability. For example, the frugivorous Troupial Icterus icterus was common on Puerto Rico (Gundlach 1878) before hurricane San Ciriaco in 1899. Afterwards, Troupials almost disappeared (Bowdish 1902, 1903, Wetmore 1927), perhaps as a result of the storm (Raffaele 1977), and only recently has the species again become common. The Puerto Rican Flycatcher Myiarchus antillarum, a tree cavity nesting species, showed a substantial decline following a hurricane in 1928 (Danforth 1936a). The White-necked Crow Corvus leucognaphalus, a frugivorous species, became rarer on Puerto Rico in 1928 after Hurricane San Felipe (Danforth 1936a). Although formerly common (Lack 1976), the frugivorous Tropical Mockingbird Mimus gilvus was not found when J.W.W. sampled sites in 1980 after two hurricanes had swept through areas on Dominica. By 1993, the mockingbird populations in Dominica had returned to prehurricane levels (G. Bertrand verbally, J.W.W. unpubl. data). The decline of the Grenada population of the Hooked-billed Kite Chondrohierax uncinatus, a terrestrial snail specialist, has been attributed, in part, to hurricane damage (Smith and Temple 1982). This explanation now appears more creditable, in light of recent findings documenting substantial post-hurricane declines in several species of terrestrial snail (Willig and Camilo 1991).

West Indian psittacines are one of the groups most vulnerable to hurricane impacts, because of their diet of fruit and seeds, cavity nesting habits and, for some, recent confinement to montane forests where vegetation recovers slowly 
after hurricane impacts. For instance, the St Vincent Parrot population declined after a hurricane in 1898 and a volcanic eruption in 1902 (Clark 1906, Nichols 1977). The population and range of the Imperial and Red-necked Amazona arausiaca Parrots of Dominica declined following two hurricanes within one year (Snyder and Snyder 1979, Gregoire 1980, Nichols 1981, Zamore 1981, Evans 1991, J.W.W. unpubl. data). In contrast, the effect of Hurricane Allen on the population of the St Lucia Parrot was characterized as not having caused a significant decline (Jeggo and Taynton 1981) and that the storm only adversely affected the possible recent upward trend of the population (Butler 1980, 1982). The Brown-throated Parakeet Aratinga pertinax was nearly extirpated from St Thomas by the hurricanes of 1926 and 1928 (Danforth 1935, Nichols 1943, Wiley 1993). Introduced populations of Green-rumped Parrotlet Forpus passerinus disappeared from parts of its former range in Jamaica following the passage of Hurricane Gilbert (Downer 1991, 1992). It is likely that the several hurricanes in the late nineteenth and early twentieth centuries played a major role in the extinction of the endemic Puerto Rican Parakeet A. maugei, by then confined to only a few small and widely separated habitat fragments. Similarly, hurricanes may have contributed to the decline and ultimate disappearance of Puerto Rican Parrots from remnant forest fragments in the Sierra de Cayey and Río Abajo, where elderly residents remembered there being many more parrots before Hurricane San Ciriaco (1899) than afterwards (Wiley 1980, Snyder et al. 1987). Finally, confirming these impressions of psittacine vulnerability to hurricanes, recent pre- and post-hurricane censuses of the Puerto Rican Parrot indicated a population decline from 47 individuals before to $20-22$ individuals immediately after Hurricane Hugo struck the Luquillo Mountains (Meyers et al. 1993).

\section{Conclusions}

Hurricanes are an important natural process that influences the structure of communities. Community patterns are determined by the complicated interplay of many components, including biotic (e.g. competition, mutualism, parasites, predators) and abiotic (e.g. temporal and spatial changes in the environment, and chance events like hurricanes) factors. Hurricanes affect distribution and colonization, species components within the community, as well as direct survival of individuals. The effects of the strong winds and heavy rains on animals and their shelter and food supplies may temporarily reduce populations or cause local extinctions. However, changes to habitat structure and composition have many beneficial effects for some bird species. Shifts in animal species composition are a consequence of habitat changes resulting from hurricanes. Most such changes are temporary as habitat succession proceeds to a climax state and wildlife populations progress through a series of community changes until a climax equilibrium is reached.

Plant and animal ecosystems in hurricane zones have evolved with these storms. These episodic events are a dynamic part of the ecology of birds in hurricane zones, and populations have adapted to these periodic storms. Thus, healthy and widespread populations should, in the long term, be able to survive hurricanes. However, with the extensive and widespread problem of habitat loss and fragmentation, many avian populations (or species) and their sup- 
porting ecosystems will become more vulnerable to extirpation or extinction. Whether by direct or indirect means, hurricanes can play a critical role in the extinction of bird populations reduced in numbers of individuals and isolated through habitat fragmentation. Along with the limited resources (i.e. carrying capacity) of fragmented habitat, other environmental changes are to be expected, e.g. exotic plant and animal invasions, resulting in competition with native species and transmission of exotic diseases. A chance hit by a severe storm may further open natural forests to exotic invaders, as well as further reduce resources and population size of the native species. Combined, these events can drive these species to extinction.

Hurricanes provide a natural experiment, wherein the effects of rapid and extreme community change can be examined. The effects of these changes on local communities can be determined through knowledge of structure before the damage and post-storm inventories. Recovery and change of the community should be monitored at intervals through the years after the storm.

\section{Acknowledgements}

We thank Robin B. Goodloe, Marshall Howe, and Michael Erwin for comments that improved an earlier draft of this manuscript. The basis of this paper was originally presented by J.W.W. at the Segundo Simposio sobre Sistemas Ecológicos Isleños - Efecto de los Huracanes en Ecosistemas Isleños, San Juan, Puerto Rico, 26 October 1984.

\section{References}

Ackerman, J. D., Walker, L. R., Scatena, F. N. and Wunderle Jr., J. M. (1991) Ecological effects of hurricanes. Bull. Ecol. Soc. America 72: 178-180.

Alleng, G. (1990) Recovery of nesting sites in the Port Royal mangroves, south coast, Jamaica, following Hurricane "Gilbert". Gosse Bird Club Broadsheet no. 55: 5-9.

Amadon, D. (1953) Migratory birds of relict distribution: some inferences. Auk 70: 461469.

Anthes, R. A. (1982) Tropical cyclones: their evolution, structure and effects. Meteorol. Monogr. 19 no. 41.

Arendt, W. J. (1990) Census and assessment of the Monterrat Oriole, other forest birds, and their habitats. Report submitted to World Wildlife Fund-US, RARE Center, Montserrat Trust.

Arendt, W. J. (1992a) Status of North American migrant landbirds in the Caribbean region: a summary. Pp. $143^{-1} 7^{1}$ in J. M. Hagan III and D. W. Johnston, eds. Ecology and conservation of Neotropical migrant landbirds. Washington, D.C.: Smithsonian Institution Press.

Arendt, W. J. (1992b) Impact of Hurricane Hugo on Pearly-eyed Thrasher reproduction in the Luquillo Rain Forest, Puerto Rico. Proc. Soc. Caribb. Ornithol. Meeting, San Juan, Puerto Rico.

Askins, R. A. and Ewert, D. N. (1991) Impact of Hurricane Hugo on bird populations on St. John, U.S. Virgin Islands. Biotropica 23: 481-487.

Askins, R. A., Lynch, J. F. and Greenberg, R. (1990) Population declines in migratory birds in eastern North America. Curr. Orn. 7: 1-57.

Baker, W. W. (1971) Progress report on life history studies of the Red-cockaded Woodpecker at Tall Timbers Research Station. Pp.44-59 in R. L. Thompson, ed. Symposium 
on the Red-cockaded Woodpecker. Tallahassee, Florida: Bur. Sport Fish. Wildl., U.S. Dept. Interior, and Tall Timbers Research Station.

Bates, C. G. (1930) Hurricane damage to Porto Rican forests. J. For. 28: 772-774.

Bagg, A. M. (1967) Factors affecting the occurrence of the Eurasian Lapwing in eastern North America. Living Bird 6: 87-121.

Beard, J. S. (1949) The natural vegetation of the Windward and Leeward Islands. Oxford: Clarendon Press.

Bell, M. W. and Klebenow, D. A. (1973) Hurricane impact on bobwhite cover. Southwestern Nat. 17: 433-435.

Bellingham, P. J. (1991) Landforms influence patterns of hurricane damage: evidence from Jamaican montane forests. Biotropica 23: 427-433.

Bellingham, P. J., Kapos, V., Varty, N., Healey, J. R., Tanner, E. V. J., Kelly, D. L., Dalling, J. W., Burns, L. S., Lee, D. and Sidrak, G. (1992) Hurricanes need not cause high mortality: the effects of Hurricane Gilbert on forests in Jamaica. J. Trop. Ecol. 8: 217-223.

Bénito-Espinal, F. P. and Bénito-Espinal, E. (1991) L'Ouragan Hugo: génèse, incidences géographiques et écologiques sur la Guadeloupe. Fort-de-France, Martinique: Imprimerie Désormeaux. (Co-editors: Parc National de la Guadeloupe, Délégation Régionale à l'Action Culturelle and Agence Guadeloupéene de l'Environnement du Tourisme et des Loisirs.

Bent, A. C. (1937) Life histories of North American birds of prey, Part 1. New York: Dover Publications.

Bond, J. (1946) The birds of Mona Island. Notulae Naturae 176.

Boucher, D. H. (1990) Growing back after hurricanes. Biotropica 40: 163-166.

Bowdish, B. S. (1902) Birds of Porto Rico. Auk 19: 356-366.

Bowdish, B. S. (1903) Birds of Porto Rico. Auk 20: 10-23.

Bradley, P. E. (1986) A report of a census of Amazona leucocephala caymanensis, Grand Cayman and Amazona leucocephala hesterna, Cayman Brac. George Town, Grand Cayman: Cayman Islands Govt. Techn. Publ. No. 1.

Brittingham, M. C. and Temple, S. A. (1983) Have cowbirds caused forest songbirds to decline? Bioscience 33: 31-35.

Brokaw, N. V. L. and Grear, J. S. (1991) Forest structure before and after Hurricane Hugo at three elevations in the Luquillo Mountains, Puerto Rico. Biotropica 23: 386392.

Brokaw, N. V. L. and Walker, L. R. (1991) Summary of the effects of Caribbean hurricanes on vegetation. Biotropica 23: 442-447.

Broley, C. L. (1951) Plight of the Florida Bald Eagle worsens. Audubon Mag. 53: 72, 136.

Broley, C. L. (1957) Bald Eagle nesting failures continue. Audubon Mag. 53: 208.

Brown, J. H. and Kodic-Brown, A. (1977) Turnover rates in insular biogeography: effects of immigration and extinction. Ecology 58: 445-449.

Buffon, G. L. L. (1779) Histoire naturelle des oiseaux, 6. Paris: L'Imprimerie Royale.

Butler, P. J. (1980) The St Lucia parrot Amazona versicolor - its changing status and its conservation. St Lucia Government.

Butler, P. J. (1982) Artificial parrot nestbox project; a summary of 1981/82 breeding seasons. Report of Forestry Division, St Lucia.

Byrd, G. V. and Tobish, T. G. (1978) Wind-caused mortality in a kittiwake colony at Buldire Island, Alaska. Murrelet 59: 37.

Cely, J. E. (1991) Wildlife effects of Hurricane Hugo. J. Coastal Res. 8: 319-326.

Cheke, A. S. (1987) The ecology of the smaller land-birds of Mauritius. Pp.151-207 in A. W. Diamond, ed. Studies of Mascarene island birds. Cambridge, U.K.: Cambridge University Press.

Clark, A. H. (1906) Birds of the southern Lesser Antilles. Proc. Boston Soc. Nat. Hist. 32: 203-312. 
Connell, J. H. (1978) Diversity in tropical rain forests and coral reefs. Science 199: 13021310.

Crow, T. R. (1980) A rain forest chronicle: a 30-year record of change in structure and composition at El Verde, Puerto Rico. Biotropica 12: 42-55.

Cruickshank, A. D. (1939) Hurricane aftermath. Auk 56: 176-179.

Danforth, S. T. (1935) Supplementary account of the birds of the Virgin Islands, including Culebra and adjacent islets pertaining to Puerto Rico, with notes on their food habits. J. Agric. Univ. Puerto Rico 19: 439-472.

Danforth, S. T. (1936a) Los pajaros de Puerto Rico. New York: Rand McNally and Co.

Danforth, S. T. (1936b) New records for Mona Island, West Indies. Auk 53: 100-101.

Darlington, P. J., Jr. (1938) The origin of the fauna of the Greater Antilles, with discussion of dispersal of animals over water and through the air. Q. Rev. Biol. 13: 274-300.

DeBenedictis, P. A. (1986) The changing seasons. Amer. Birds 40: 75-82.

Denslow, J. S. (1987) Tropical rain forest gaps and tree species diversity. Ann. Rev. Ecol. Syst. 18: 431-452.

Diamond, J. M. (1972) Biogeographic kinetics: estimation of relaxation times for avifaunas of southwest Pacific islands. Proc. Natn. Acad. Sci. 69: 3199-3203.

Dinsmore, J. J. (1970) History and natural history of Paradisaea apoda on Little Tobago Island, West Indies. Carib. J. Sci. 10: 93-100.

Downer, A. (1991) Green-rumped Parrotlet. Gosse Bird Club Broadsheet 57: 22.

Downer, A. (1992) Green-rumped Parrotlet. Gosse Bird Club Broadsheet 58: 21.

Doyle, T. W. (1981) The role of disturbance in the gap dynamics of a montane rain forest: an application of a tropical forest successional model. Pp.56-73 in D. C. West, H. H. Shugart and D. B. Botkin, eds. Forest succession: concepts and applications. New York: Springer-Verlag.

Dunning, J. B., Jr. and Watts, B. D. (1991) Habitat occupancy by Bachman's Sparrow in the Francis Marion National Forest before and after Hurricane Hugo. Auk 108: 723725 .

Emanuel, K. A. (1987) The dependence of hurricane intensity on climate. Nature 326: $483-485$.

Engstrom, R. T. and Evans, G. W. (1990) Hurricane damage to Red-cockaded Woodpecker (Picoides borealis) cavity trees. Auk 107: 608-610.

Evans, P. G. H. (1991) Status and conservation of Imperial and Red-necked Parrots Amazona imperalis and A. arausiaca on Dominica. Bird Conserv. Internatn. 1: 11-32.

Ewens, W. J., Brockwell, P. J., Gant, J. M. and Resnick, S. I. (1987) Minimum viable population size in the presence of catastrophes. Pp.59-68 in M. E. Soulé, ed. Viable populations for conservation. Cambridge, U.K.: Cambridge University Press.

Eynon, A. E. (1951) Gale-damaged oak forest on Trap Rock Ridge. Audubon Field Notes 5: 322-323.

Eynon, A. E. (1954) Gale-damaged oak forest. Audubon Field Notes 8: 365-366.

Ferrigno, F. and Widjeskow, L. (1977) Clapper rail mortality resulting from Hurricane Belle. New Jersey Outdoors 4: 13.

Finkl, C. W. and Pilkey, O. H., eds. (1991) Impacts of Hurricane Hugo: September 1022, 1989. J. Coastal Res. Special Issue no. 8.

Fisk, E. J. (1979) Fall and winter birds near Homestead, Florida. Bird-Banding 50: 224-243

Fletcher, J. (1989) [Post-hurricane observations]. Gosse Bird Club Broadsheet no. 52: 8-9.

Frangi, J. L. and Lugo, A. E. (1991) Hurricane damage to a flood plain forest in the Luquillo Mountains of Puerto Rico. Biotropica 23: 324-335.

Galli, A. B., Leck, C. B. and Forman, R. T. T. (1976) Avian distribution patterns in forest islands of different sizes in central New Jersey. Auk 93: 356-364.

Gates, J. E. and Gysel, L. W. (1978) Avian nest dispersion and fledging success in field-forest ecotones. Ecology 59: 871-883.

Gregoire, F. (1980) The dilemma of the Amazona imperialis and A. arausiaca parrots in 
Dominica following Hurricane David in 1979. Pp.161-167 in R. F. Pasquier, ed. Conservation of New World parrots. Washington, D.C.: Smithsonian Institution Press for the International Council for Bird Preservation (Techn. Publ. 1).

Gresham, C. A., Williams, T. M. and Lipscomb, D. J. (1991) Hurricane Hugo wind damage to southeastern U.S. coastal forest tree species. Biotropica 23: 420-426.

Gundlach, J. (1878) Apuntes para la fauna puerto-riqueña: Aves. Ann. Soc. Espan. Hist. Nat., Madrid 7: 141-234, 343-422.

Gunter, G. and Eleuterius, L. N. (1971) Some effects of hurricanes on terrestrial biota, with special reference to Camille. Gulf Res. Rep. 3: 283-289.

Hall, G. A. (1981) The changing seasons. Amer. Birds 35: 150-156.

Hamel, P. B. (1986) Bachman's Warbler: a species in peril. Washington, D.C.: Smithsonian Press.

Hartman, F. E. and Wunz, G. A. (1974) Did Hurricane Agnes hurt our wildlife supply? Pennsylvania Game News 45: 44-46.

Heatwole, H. and Levins, R. (1973) Biogeography of the Puerto Rican bank: speciesturnover on a small cay, Cayo Ahogado. Ecology 54: 1042-1055.

Helmuth, W. T., III (1954) The hurricane of 1938 - in retrospect. Birds Long Island 8: 225241.

Hill, N. P. (1945) The 1944 hurricane in New England. Auk 62: 410-413.

Holliman, D. C. (1981) A survey of the September 1979 hurricane damage to Alabama Clapper Rail habitat. Northeast Gulf Sci. 5: 95-98.

Holmes, R. T. and Sherry, T. W. (1992) Site fidelity of migratory warblers in temperate breeding and neotropical wintering areas: implications for population dynamics, habitat selection, and conservation. Pp.563-575 in J. M. Hagan, III and D. W. Johnston, eds. Ecology and conservation of Neotropical migrant landbirds. Washington, D.C.: Smithsonian Institution Press.

Hooper, R. G., Watson, J. C. and Escano, R. E. F. (1990) Hurricane Hugo's initial effects on Red-cockaded Woodpeckers in the Francis Marion National Forest. Trans. 55th N.A. Wildl. and Nat. Res. Conf. 55: 220-224.

Huntington, J. L. and Barbour, T. (1936) The birds at Soledad, Cuba, after a hurricane. Auk 53: 436-437.

Huston, M. (1979) A general hypothesis of species diversity. Amer. Nat. 113: 81-101.

Jackson, J. A., Lennartz, M. R. and Hooper, R. G. (1979) Tree age and cavity initiation by Red-cockaded Woodpeckers. J. For. 77: 102-103.

Jeffrey-Smith, M. (1953) Starlings in St Anne. Nat. Hist. Notes Nat. Hist. Soc. Jamaica 5: 213.

Jeggo, D. F. and Taynton, K. M. (1981) The effects of Hurricane Allen on the status of the St Lucia Parrot Amazona versicolor. Dodo 17: 11-18.

Jones, G. C. (1980) Parrot on the way to extinction. Oryx 15: 350-354.

Jones, C. G. (1987) The larger land-birds of Mauritius. Pp.208-300 in A. W. Diamond, ed. Studies of Mascarene island birds. Cambridge, U.K.: Cambridge University Press.

Kennedy, R. J. (1970) Direct effects of rain on birds: a review. Brit. Birds 63: 401-414.

King, W. B. (1978) Endangered birds of the world and current efforts toward managing them. Pp.9-17 in S. A. Temple, ed. Endangered birds: management techniques for preserving threatened species. Madison: University of Wisconsin Press.

Labat, J. B. (1742) Nouveau voyage aux isles de l'Amerique. Paris.

Lack, D. (1976) Island biology illustrated by the land birds of Jamaica. Berkeley, California: University of California Press.

Lack, D. and Lack, P. (1972) Wintering warblers in Jamaica. Living Bird 11: 129-153.

Legrand, H. E., Jr. (1985) Southern Atlantic Coast Region. Amer. Birds 39: 899-902.

Lennartz, M. R., Knight, H. A., McClure, J. P. and Rudis, V. A. (1983) Status of Redcockaded Woodpecker nesting habitat in the south. Pp.13-19 in D. A. Wood, ed. 
Proc. Red-cockaded Woodpecker Symp. II. Gainesville, Florida: Game Fresh Water Fish Commission, U.S. Fish and Wildlife Service, and U.S. Forest Service.

Levin, S. A. and Paine, R. T. (1974) Disturbance, patch formation, and community structure. Proc. Natn. Acad. Sci. 71: 2744-2747.

Loucks, O. L. (1970) Evolution of diversity, efficiency, and community stability. Amer. Zool. 10: 17-25.

Lowery, G. H., Jr. (1946) Evidence of trans-gulf migration. Auk 63: 175-211.

Lugo, A. E., Applefield, M., Pool, D. J. and McDonald, R. B. (1983) The impact of Hurricane David on the forests of Dominica. Canada J. For. Res. 13: $201-211$.

Lugo, A. E., Snell, M. and Snedaker, S. C. (1976) Mangrove ecosystem analysis. Pp.113145 in B. C. Patten, ed. System analysis and simulation ecology, 4. New York: Academic Press.

Lynch, J. F. (1991) Effects of hurricane Gilbert on birds in a dry tropical forest in the Yucatan Peninsula. Biotropica 23: 488-496.

Mayhew, D. F. (1949) Atmospheric pressure and bird flight. Science 109: 403.

MacArthur, R. H. and Wilson, E. O. (1967) The theory of island biogeography. Princeton, New Jersey: Princeton University Press.

McClure, H. E. (1945) Effects of a tornado on birdlife. Auk 62: 414-418.

McNicholl, M. K. (1979) Destruction of nesting birds on a marsh bay by a single storm. Prairie Nat. 11: 60-62.

McNicholl, M. K. and Hogan, G. C. (1979) Wind-caused death of Great Cormorant. Canadian Field-Nat. 93: 175.

Meyers, J. M., Vilella, F. J. and Barrow, Jr., W. C. (1993) Positive effects of Hurricane Hugo: record years for Puerto Rican Parrot nesting in the wild. Endangered Species Techn. Bull. 18: 1, 10.

Moore, N. W. and Hooper, M. D. (1975) On the number of bird species in British woods. Biol. Conserv. 8: 239-250.

Morton, E. S. (1990) Habitat segregation by sex in the hooded warbler: experiments on proximate causation and discussion of its evolution. Amer. Nat. 135: 319-333.

Morton, E. S., van der Voort, M. and Greenberg, R. (1993) How a warbler chooses its habitat: field support for laboratory experiments. Anim. Behav. 46: 47-53.

Murphy, R. C. (1934) Stray seabird and Atlantic storm tracks. Geogr. Rev. 1934: 151-152.

Murphy, R. C. and Vogt, W. (1933) The Dovekie influx of 1932. Auk 50: 325-349.

Nalivkin, D. V. (1983) Hurricanes, storms and tornadoes. Rotterdam: A. A. Balkema.

Neumann, C. J., Jarvin, B. R. and Pike, A. C. (1990) Tropical cyclones of the North Atlantic Ocean, 1871-1986. Asheville, N.C.: National Climatic Data Center (Historical Climatology Series 6-2).

Newman, R. J. and Andrle, R. F. (1961) The changing seasons. Audubon Field Notes 15: 4-7.

Nicholls, R. A. (1943) The breeding birds of St. Thomas and St. John, Virgin Islands. Mem. Soc. Cubana Hist. Nat. "Felipe Poey" 17: 23-37.

Nichols, H. A. J. (1977) Captive breeding programmes for Amazon parrots. Pp.263-271 in S. A. Temple, ed. Endangered birds: management techniques for preserving threatened species. Madison: University of Wisconsin Press.

Nichols, T. D. (1981) Observations on Amazona imperialis during the second nesting season after Hurricane David. Report to I.C.B.P.

Odum, H. T. (1970) Rainforest structure and mineral-cycling homeostasis. $\mathrm{Pp}_{\mathrm{H}} \mathrm{H}_{3}-52$ in H. T. Odum and R. F. Pigeon, eds. A tropical rainforest. Springfield, Virginia: National Technical Information Services.

Olson, S. L. (1984) The last St. Kitts Bullfinch, Loxigilla portoricensis grandis (Emberizinae), and the extinction of its race. Bull. Brit. Orn. Club 104: 121-124. 
Paine, R. T. (1979) Disaster, catastrophe, and local persistence of the sea palm Postelsia palmaeformis. Science 205: 685-687.

Pangburn, C. H. (1948) Hurricane in southern Florida brings rarities to northern part of state. Auk 65: 608-609.

Pérez-Rivera, R. A. (1991) Change in diet and foraging behavior of the Antillean Euphonia in Puerto Rico after Hurricane Hugo. J. Field Orn. 62: 474-478.

Peterson, R. T. (1948) Birds over America. New York: Dodd, Mead and Co.

Pettingill, O. S., Jr. (1970) Ornithology in the laboratory and field. Minneapolis, Minnesota: Burgess Publ. Co.

Pickett, S. T. A. and White, P. S. (1985) The ecology of natural disturbance and patch dynamics. New York: Academic Press.

Pierce, J. (1990) Effects of Hurricane Hugo on cay-nesting avifauna in the U.S. Virgin Islands. Colonial Waterbird Soc. Newsl. 14: 23.

Pierce, J. (1991) Red-billed Tropicbird breeding in the United States Virgin Islands. Colonial Waterbird Soc. Newsl. 15: 33.

Platt, G., Evans, G. and Engstrom, T. (1986) The legacy of Kate. Tall Timbers Rep. 8: $1-2$.

Porter, S. (1929) In search of the Imperial Parrot. Avicult. Mag. (4)7: 240-246, 267-275.

Post, W. and Wiley, J. W. (1976) The Yellow-shouldered Blackbird - present and future. Amer. Birds 30: 13-20.

Post, W. and Wiley, J. W. (1977) The Shiny Cowbird in the West Indies. Condor 79: 119121.

Potts, F. A. (1927) Notes on Porto Rican birds. Auk 44: 120-121.

Putz, F. E. and Sharitz, R. R. (1991) Hurricane damage to old-growth forest in Congree Swamp National Monument, South Carolina, U.S.A. Can. J. For. Res. 21: 1765-1770.

Raffaele, H. A. (1973) Assessment of Mona Island avifauna. Apendice $\mathrm{K}$ in Las Islas de Mona y Monito: una evaluación de sus recursos naturales e históricos. Puerto Rico: Junta de Calida Ambiental, Estado Libre Asociado de Puerto Rico.

Raffaele, H. A. (1977) Comments on the extinction of Loxigilla portoricensis grandis in St Kitts, Lesser Antilles. Condor 79: 389-390.

Raffaele, H. A. and Roby, D. (1977) The Lesser Antillean Bullfinch in the Virgin Islands. Wilson Bull. 89: 338-342.

Reagan, D. P. (1991) The response of Anolis lizards to hurricane-induced habitat changes in a Puerto Rican rain forest. Biotropica 23: 468-474.

Reilly, A. E. (1991) The effects of Hurricane Hugo in three tropical forests in the U.S. Virgin Islands. Biotropica 23: 414-419.

Robertson, W. B. and Kushlan, J. A. (1974) The southern Florida avifauna. Pp.414-452 in Memoir 2: Environments of south Florida: present and past. Miami: Miami Geological Society.

Robertson, W. B. and Paulson, D. R. (1961) Florida region. Audubon Field Notes 15: 26-35. Ryel, L. A. (1981) Population change in the Kirtland's Warbler. Jack-Pine Warbler 59: 76-91.

Saffir, H. S. (1991) Hurricane Hugo and implications for design professionals and codewriting authorities. J. Coastal Res. Special Issue no. 8: 25-32.

Saliva, J. E. (1989) Possible effects of Hurricane Hugo on the seabird populations of Culebra Island. Colonial Waterbird Soc. Newsl. 13: 33.

Schmida, A. and Wilson, M. V. (1985) Biological determinants of species diversity. J. Biogeogr. 12: 1-20.

Schmitz, R. A. and Baldassarre, G. A. (1992) Correlates of flock size and behavior of foraging American Flamingos following Hurricane Gilbert in Yucatan, Mexico. Condor 94: $260-264$.

Schmitz, R. A., Alonso Aguirre, A., Cook, R. S. and Baldassarre, G. A. (1990) Lead poisoning of Caribbean Flamingos in Yucatan, Mexico. Wildl. Soc. Bull. 18: 399-404. 
Shepherd, P., Crockett, T., De Santo, T. L. and Bildstein, K. L. (1991) The impact of Hurricane Hugo on the breeding ecology of wading birds at Pumpkinseed Island, Hobcaw Barony, South Carolina. Colonial Waterbirds 14: 150-157.

Smith, T. B. and Temple, S. A. (1982) Grenada Hook-billed Kites: recent status and life history notes. Condor $84: 131$.

Snyder, N. F. R. (1977) Puerto Rican Parrots and nest site scarcity. Pp.41-53 in S. A. Temple, ed. Endangered birds: management techniques for preserving threatened species. Madison: University of Wisconsin Press.

Snyder, N. F. R. and Snyder, H. A. (1979) Report to I.C.B.P. on an assessment of the status of parrots of Dominica following Hurricane David. Unpubl. report to I.C.B.P.

Snyder, N. F. R., Wiley, J. W. and Kepler, C. B. (1987) The parrots of Luquillo: natural history and conservation of the Puerto Rican parrot. Los Angeles: Western Foundation of Vertebrate Zoology.

Sparks, P. R. (1991) Wind conditions in Hurricane Hugo and their effects on buildings in coastal South Carolina. J. Coastal Res. Special Issue no. 8: 13-24.

Stiles, F. G. (1983) Introduction to birds of Costa Rica. Pp.502-530 in D. H. Janzen, ed. Costa Rican natural history. Chicago: University of Chicago Press.

Sutton, G. M. (1945) Behavior of birds during a Florida hurricane. Auk 62: 603-606.

Swindell, D. D. (1950) Gulf Hammock Wildlife Investigation. Tallahassee: unpublished report, Florida Game and Freshwater Fish Commission.

Tanner, E. V. J., Kapos, V. and Healey, J. R. (1991) Hurricane effects on forest ecosystems in the Caribbean. Biotropica 23: 513-521.

Temple, S. A. (1978) The life histories and ecologies of the indigenous landbirds of Mauritius. Unpublished report.

Terborgh, J. (1990) Where have all the birds gone? Princeton, New Jersey: Princeton University Press.

Tomkins, I. R. (1934) Hurricanes and subspecific variation. Wilson Bull. 46: 238-240.

Thompson, D. A. (1983) Effects of Hurricane Allen on some Jamaican forests. Commonw. For. Rev. 62: 107-115.

Thompson, L. (1900) Notes on the St. Vincent Parrot. Avicult. Mag. 6: 147-149.

Threlfall, W., Eveleigh, E. and Maunder, J. E. (1974) Seabird mortality in a storm. Auk 91: 846-849.

Thurber, W. A. (1980) Hurricane Fifi and the 1974 autumn migration in El Salvador. Condor 82: 212-218.

Torres, J. A. (in press) Lepidoptera outbreaks in response to successional changes after the passage of Hurricane Hugo in Puerto Rico. J. Trop. Ecol.

Trautman, M. B. (1979) Experiences and thoughts relative to the Kirtland's Warbler. Jack-Pine Warbler 57: 135-140.

U.S. Fish and Wildlife Service (1985) Red-cockaded Woodpecker recovery plan. Atlanta, Georgia: U.S. Fish and Wildlife Service.

U.S. Forest Service (1985) Land and resource management plan - Francis Marion National Forest. Columbia, South Carolina: USDA Forest Service.

Varty, N. (1991) The status and conservation of Jamaica's threatened and endemic forest avifauna and their habitats following Hurricane Gilbert. Bird Conserv. Internatn. 1: 135151.

Wadsworth, F. H. and Englerth, G. W. (1959) Effects of the 1956 hurricane on forests in Puerto Rico. Carib. For. 20: 38-51.

Waide, R. B. (1991a) The effect of Hurricane Hugo on bird populations in the Luquillo Experimental Forest, Puerto Rico. Biotropica 23: 475-480.

Waide, R. B. (1991b) Summary of the response of animal populations to hurricanes in the Caribbean. Biotropica 23: 508-512. 
Walker, L. R. (1991) Tree damage and recovery from Hurricane Hugo in Luquillo Experimental Forest, Puerto Rico. Biotropica 23: 379-385.

Walker, L. R., Brokaw, N. V. L., Lodge, D. J. and Waide, R. B., eds. (1991) Ecosystem, plant, and animal responses to hurricanes in the Caribbean. Biotropica 23(4).

Wauer, R. H. and Wunderle, Jr., J. M. (1992) The effect of Hurricane Hugo on bird populations on St. Croix, U.S. Virgin Islands. Wilson Bull. 104: 656-673.

Weaver, P. L. (1986) Hurricane damage and recovery in the montane forests of the Luquillo Mountains. Carib. J. Sci. 22: 53-70.

Webster, J. D. (1963) Tornado-disturbed beech-maple forest. Audubon Field Notes 17: 496497 .

Webster, J. D. (1964) Tornado-disturbed beech-maple forest. Audubon Field Notes 18: 548549 .

Wetmore, A. (1927) The birds of Porto Rico and the Virgin Islands. New York Acad. Sci., Sci. Surv. Porto Rico Virgin Islands 9: 245-571.

Wetmore, A. (1931) The Hudsonian Godwit in the Dominican Republic. Auk 48: 596597.

Whitcomb, R. F., Robbins, C. S., Lynch, J. F., Whitcomb, B. L., Klimkiewicz, M. K. and Bystrak, D. (1981) Effects of forest fragmentation on avifauna of the eastern deciduous forest. Pp.125-205 in R. L. Burgess and D. M. Sharpe, eds. Forest-island dynamics in man-dominated landscapes. New York: Springer-Verlag.

Whitmore, T. C. (1974) Change with time and the role of cyclones in tropical rain forest on Kolombangara, Solomon Islands. Oxford: Commonwealth Forestry Institute (Institute Paper 46).

Wiley, J. W. (1980) The Puerto Rican parrot (Amazona vittata): its decline and the program for its conservation. Pp.133-159 in R. F. Pasquier, ed. Conservation of New World parrots. Washington, D.C.: Smithsonian Institution Press for the International Council for Bird Preservation (Techn. Publ. 1).

Wiley, J. W. (1985a) The Puerto Rican Parrot and competition for its nest sites. Pp.213223 in P. J. Moors, ed. Conservation of island birds. Cambridge, U.K.: International Council for Bird Preservation (Techn. Publ. 3).

Wiley, J. W. (1985b) Shiny Cowbird parasitism at two avian communities in Puerto Rico. Condor 87: 165-176.

Wiley, J. W. (1993) Natural range expansion and local extirpation of an exotic psittacine an unsuccessful colonization attempt. Ornitologia Neotropical 4: 43-54.

Will, T. (1991) Birds of a severely hurricane-damaged Atlantic coast rain forest in Nicaragua. Biotropica 23: 497-507.

Willig, M. R. and Camilo, G. R. (1991) The effect of Hurricane Hugo on six invertebrate species in the Luquillo Experimental Forest of Puerto Rico. Biotropica 23: 455-461.

Willis, E. O. (1974) Populations and local extinctions of birds on Barro Colorado Island, Panama. Ecol. Monogr. 44: 153-159.

Wolcott, G. N. (1932) The effect of the hurricane of San Cyprian on insects in Puerto Rico. Insect Pest Surv. Bull. 12: 409-410.

Woodley, J. D., Chornesky, E. A., Clifford, P. A., Jackson, J. B. C., Kaufman, L. S., Knowlton, N. et al. (1981) Hurricane Allen's impact on Jamaican coral reefs. Science 214: $749-755$.

Woods, G. T. (1940) New England hurricane benefits wildlife. Amer. For. 46: 402-404.

Woolbright, L. L. (1991) The impact of Hurricane Hugo on forest frogs in Puerto Rico. Biotropica 23: 462-467.

Wunderle, J. M. (1990) The effect of Hurricane Hugo on bird populations in a Puerto Rican rain forest. Abstract, Wilson Ornithological Society meeting, Norton, Massachussetts.

Wunderle, J. M., Jr., Diaz, A., Vlazquez, I. and Scharron, R. (1987) Forest openings and the distribution of understory birds in a Puerto Rican rainforest. Wilson Bull. 99: 22-37. 
Wunderle, J. M., Jr., Lodge, D. J. and Waide, R. B. (1992) Short-term effects of Hurricane Gilbert on terrestrial bird populations on Jamaica. Auk 109: 148-166.

You, C. and Petty, W. H. (1991) Effects of Hurricane Hugo on Manilkara bidentata, a primary tree species in the Luquillo Experimental Forest of Puerto Rico. Biotropica 23: 400-406.

Yunick, R. P. (1977) A Caribbean Barn Swallow recovery. Auk 94: 149-150.

Zamore, M. (1981) Emergency protection for the Amazona parrots of Dominica following the passage of Hurricane David. Report of Forestry Division, Commonwealth of Dominica, Roseau.

JAMES W. WILEY

National Biological Survey, Division of Cooperative Research, Washington, D.C. 20240, U.S.A. Mailing address: Grambling Cooperative Wildlife Project, P.O.Box 4290, Grambling State University, Grambling, Louisiana 71245, U.S.A.

JOSEPH M. WUNDERLE, JR.

International Institute of Tropical Forestry, U.S. Department of Agriculture - Forest Service, Box B, Palmer, Puerto Rico 00721, West Indies. 